\title{
Effect of packaged tea drinks consumption to corrosion rate of stainless steel orthodontic wire
}

\author{
Mansjur Nasir, ${ }^{*}$ Rafiqah R. Amelia
}

\section{Abstract}

Objective: To determine the effect of packaged tea drinks consumption to corrosion rate of stainless steel orthodontic wire.

Material and Methods: This study is laboratory experimental with post-test only with control group design using stainless steel orthodontic wire with total of 16 samples. The wire length is $6 \mathrm{~cm}$ and diameter is $0.41 \mathrm{~mm}$. Samples were divided into 4 groups with 1 group of artificial saliva and 3 groups with a packaged tea drinks substitution. Measurement of corrosion rate was done by using potensiostat tool and data analysis using SPSS version 23 and ANOVA test with significant value of $p<0.05$.

Results: Jasmine and fruit flavor packaged tea group had lower corrosion rate value than the control group. While green packaged tea group had higher corrosion rate value than the control group. Conclusion: Green packaged tea drinks had the biggest effect on corrosion rate of stainless steel orthodontic wire.
Department of Orthodontic, Faculty of Dentistry, Hasanuddin University, Makassar, Indonesia
*Correspondence to: Mansjur Nasir, Departmen of Orthodontic, Faculty of Dentistry, Hasanuddin University, Makassar, Indonesia mansjurnasir@gmail.com

Received: 6 August 2020 Revised: 70 ctober 2020 Accepted: 18 February 2021 Available Online: 1 August 2021

Keywords: Corrosion, Orthodontic wire, Packaged tea drinks, Potensiostat, Stainless steel

Cite this Article: Nasir M, Amelia RR. 2021. Effect of packaged tea drinks consumption to corrosion rate of stainless steel orthodontic wire. Journal of Dentomaxillofacial Science 6(2): 84-87. D0I: 10.15562/jdmfs.v6i2.1086

\section{Introduction}

Malocclusion is a condition which malrelation occurs in dental arch. ${ }^{1}$ Malocclusion can effect someone's orofacial form, so that it can effect social interaction, psychology condition, self confidence, and unsatisfication of apperances. ${ }^{2}$

One of the treatment that can be used to correct malocclusion is using fixed orthodontic appliances. Fixed orthodontic appliance is an appliance that contact with patient's tooth so that it can't be removed by patient itself. This appliance consists of three main components, such as attachment (can be bracket or band), archwire and accessories or auxiliaries (can be elastomeric chain and modul). ${ }^{3}$

Orthodontic archwire is one of the most important component in orthodontic treatment. ${ }^{4}$ There are many types of orthodontic archwire, some of them are nickel titanium, stainless steel, CuNiTi, and beta titanium. ${ }^{5}$ Stainless steel archwire is a wire that's commonly used in orthodontic treatment. This wire has advantages such as good biocompability, stability, elastic deformity, and strength, it's also cheaper, and resistant to corossion..$^{5-7}$

Orthodontic wire in fixed appliances always contacts with saliva and oral tissues. In oral condition, wire that's used in orthodontic treatment has a potency to release alloy. ${ }^{4}$ Corrosion also known as a metal damage because of metalurgic factor and chemistry reaction with its environment which cause decrease of metal material quality. ${ }^{8}$ This happens because oral cavity is an ideal environment to metal biodegradation occurs because of its temperature, and quality and $\mathrm{pH}$ of saliva that can effect metal ion stability. ${ }^{5}$

Corrosion of stainless steel orthodontic wire in oral cavity can cause metal ion releasing. Released metal ion, especially $\mathrm{Cr}$ and $\mathrm{Ni}$ can cause bad impact on quality, aesthetic, physic, and strength of the wire; it also can effect patient's health such as allergic reaction, toxic and cariogenic effect in human body. ${ }^{4,5}$

Metal ion releasing can be happened because of temperature, microflora, and enzym in oral cavity, and $\mathrm{pH}$ of saliva. ${ }^{4} \mathrm{pH}$ of saliva changes everytime. One of the reason of its changing is packaged drink consumption, such as tea packaged. ${ }^{9}$ But, this theory is inversely proportional with the characteristic of pure tea leaves that can inhibit corrosion rate because it has tanin around 7\%-15\%.,10 Because of that, researcher wants to know the effect of tea packaged consumption to corrosion rate of stainless steel orthodontic wire.

\section{Material and Methods}

This study is an experimental laboratory research, using post-test with control group design. This study was held in September 2018 on Laboratorium Biokimia and Laboratorium Kimia Terpadu Jurusan Kimia Fakultass MIPA, and Laboratorium Oral Biologi FKG Universitas Hasanuddin.

The research design used in this study is completely randomized design (CRD), which consists of 4 groups with each 4 samples per treatment group, so there are 16 attempts. 
The tools used in this study a beaker, glass, potentiostat EDAQ, analytic scales, stir bar, refrigerator, cutting pliers, adam pliers. While the materials used are jasmine flavor, fruit flavor and green tea package drinks, cork, artificial saliva, orthoform ovoid lower jaw orthodontic wire made from stainless steel, $\mathrm{pH}$ indicator strips, aluminum foil.

Preparation of Artificial Saliva; This composition based on Fusayama Meyer: ${ }^{11-13} \mathrm{KCl}: 0.4 \mathrm{~g} / \mathrm{L}, \mathrm{NaCl}$ : $0.4 \mathrm{~g} / \mathrm{L}, \mathrm{CaCl} 2.2 \mathrm{H} 2 \mathrm{O}: 0906 \mathrm{~g} / \mathrm{L}, \mathrm{NaH} 2 \mathrm{PO} 4.2 \mathrm{H} 2 \mathrm{O}$ : $0.690 \mathrm{~g} / \mathrm{L}, \mathrm{NaS} 2.9 \mathrm{H} 2 \mathrm{O}: 0.005 \mathrm{~g} / \mathrm{L}$, urea: $1 \mathrm{~g} / \mathrm{L}$. This saliva was made around 2 litre with $\mathrm{pH} 6,5{ }^{13}$

Orthodontic Wire Preparation; Wire used in this research was 8 of stainless steel wires with diametre $0,41 \mathrm{~mm}$, then each wire was cut into 2 with the length $6 \mathrm{~cm}$. The wire then weighed using analytic scales.

$\mathrm{pH}$ Measurement; Before the measurement, artificial saliva was mixing with jasmine, fruit, and green packaged tea with each $500 \mathrm{ml}$ in a beaker, $\mathrm{pH}$ strip was put into the glass then wait a few moment, after the color of strip changed, that color was matched with the $\mathrm{pH}$ indicator to determine the solution's $\mathrm{pH}$.

Corrosion Rate Measurements; Preparation of the solution that has been done $\mathrm{pH}$ measurement, laptop and potentiostat instrument is turned on, then connected via a USB connection, artificial saliva was poured into a glass beaker of $100 \mathrm{ml}$ and then closed with a cork that has been given a three-hole for supporting electrode, comparative electrode and working electrode, supporting electrode (Pt electrode), dipped into a glass and then connected with red port cable, comparative electrode ( $\mathrm{Ag} / \mathrm{AgCl}$ electrode) is dipped into a glass and then connected wirh yellow port cavle, and the working electrode (stainless steel orthodontic wire) dipped into the glass then connected to green port cable, echem v.2.1.2 software is opened and set potential range and speed measurement. In this study, the potential range used is equal to $-600 \mathrm{mV}$ to $600 \mathrm{mV}$ with measurement speed $25 \mathrm{mV} / \mathrm{s}$ and a current of $100 \mathrm{~mA}$ and $500 \mathrm{uA}$, measurement then begins to completion, the measurement was repeated again by using artificial saliva mixed drink jasmine tea, fruit-flavored tea, and green packaged tea, the measurement results using this software then transferred to Microsoft Excel and then processed to create Tafel graphs to obtain the rate of corrosion of orthodontic wires using the equation: ${ }^{14}$

$$
\text { Rmpy }=\frac{0.13 \text { Icorr E }}{\rho}
$$

\section{Information:}

Rmpy : The corrosion rate (milli-inch / year)

Icorr : Corrosion current density $\left(\mathrm{uA} / \mathrm{cm}^{2}\right)$

E : The weight of an equivalent material (g)

$\rho \quad$ : Material density $\left(\mathrm{g} / \mathrm{cm}^{3}\right)$

\section{Results}

Table 1 shows the difference to the average rate of corrosion of the stainless steel wire (Mpy) after soaking the control solution, jasmine tea drinks, fruitflavored tea, and green packaged tea. The results based on descriptive statistical analysis showed that the average rate of corrosion of the wire are highest in the group given the treatment by soaking green tea solution that is equal to $0.00174125 \mathrm{mpy}$, while the average rate of corrosion of stainless steel wire are lowest in the group given the treatment with a solution of fruit flavor tea that is equal to 0.00067050 mpy. Groups of samples were soaked with control treatment obtain the average corrosion rate of $0.00120550 \mathrm{mpy}$, while the samples treated with a solution of jasmine tea obtain the average corrosion rate of 0.00115625 mpy.

Table 1 also shows the results of the normality test to determine the statistical tests to be used in this research. The results of Shapiro Wilk normality test showed $p>0.05$ in all groups. This shows that all groups are normally distributed. So that it qualified to use parametric test which is One Way Anova.

One Way ANOVA parametric test only gives an indication of whether there is a difference between individual treatment to each other treatments. ANOVA test results can be seen as follows:

Based on table 2 shows the results of ANOVA test based on the statistical value of $\mathrm{F}$ on the line Between Groups obtained at 13 352. It can be concluded that there is at least one soaking treatment that affect the rate of corrosion. In addition, the $\mathrm{F}$ test for treatment shows that the p-value obtained is smaller than 0.05 so that the immersion affects the rate of corrosion.

Overall treatment performed experimental design has a significant effect against corrosion rate. But not necessarily the average of the different soaking treatment by immersion is not given treatment (control). Based on this, it is necessary to further test (Post Hoc Tests). 
Table 1 The average difference in the rate of corrosion of stainless steel wire (mpy) after soaking the control solution, jasmine tea drinks, fruit-flavored tea, green packaged tea

\begin{tabular}{|c|c|c|c|c|}
\hline \multirow[b]{2}{*}{ Treatment } & \multirow{2}{*}{$\begin{array}{c}\text { Total } \\
\text { Sample (N) }\end{array}$} & \multicolumn{2}{|c|}{ Descriptive statistics } & \multirow{2}{*}{$\begin{array}{c}\text { Test normality } \\
\text { P-value }\end{array}$} \\
\hline & & The ra & corrosion & \\
\hline \multirow{2}{*}{ Control } & \multirow{2}{*}{4} & mean & 0.00120550 & \multirow{2}{*}{$0928^{*}$} \\
\hline & & SD & 0.00044068 & \\
\hline \multirow{2}{*}{ Jasmine tea } & \multirow{2}{*}{4} & mean & 0.00115625 & \multirow{2}{*}{0700 * } \\
\hline & & SD & 0.00016394 & \\
\hline \multirow{2}{*}{ Tea Flavor Fruit } & \multirow{2}{*}{4} & mean & 0.00067050 & \multirow{2}{*}{$0.867^{\star}$} \\
\hline & & SD & 0.00008903 & \\
\hline \multirow{2}{*}{ Green tea } & \multirow{2}{*}{4} & mean & 0.00174125 & \multirow{2}{*}{0.182 * } \\
\hline & & SD & 0.00002657 & \\
\hline
\end{tabular}

* Shapiro-Wilk test: $p>0.05$; normal distribution of the data

Table 2 Anova test results

\begin{tabular}{lccccc}
\hline $\begin{array}{l}\text { The rate of } \\
\text { corrosion }\end{array}$ & $\begin{array}{c}\text { Sum of } \\
\text { Squares }\end{array}$ & df & $\begin{array}{c}\text { mean } \\
\text { Square }\end{array}$ & F & p-value \\
\hline Between Groups & 0000 & 3 & 0000 & 13352 & 0000 * \\
Within Groups & 0000 & 12 & 0000 & & \\
Total & 0000 & 15 & & &
\end{tabular}

* Anova One Way Test:- $<0.05$; significant

Table 3 The results of different tests simultaneously rtaa Average corrosion rate of stainless steel wire ( $\mathrm{mpy}$ ) between the control solution immersion, jasmine tea drinks, fruitflavored tea, and green tea packaging

\begin{tabular}{llcc}
\hline Treatment & & Difference Averages & p-value \\
\hline Control & Jasmine tea & 0.0000493 & 1 \\
& Tea Flavor Fruit & $0.000535000^{*}$ & $0: 05^{\star}$ \\
& Green tea & $-0.000535750^{\star}$ & $0049{ }^{*}$ \\
\hline
\end{tabular}

* Post Hoc Test: Mann Whitney test:- $<0.05$; significant

Table 3 shows that the results of different tests simultaneously average corrosion rate of stainless steel wire between the control solution immersion, jasmine, fruit-flavored, and green packaged tea. The results obtained indicate a difference in the corrosion rate of 0.0000493 mpy difference between the control group and the group jasmine packaged tea solution with the corrosion rate obtained was lower than the corrosion rate of the control group because the average difference obtained is positive. For the average difference between the control group and fruit-flavored packaged tea solution obtained with a difference of 0.000535000 mpy corrosion rate be lower than the rate of corrosion control group because the average difference obtained is positive. And, the average difference between the control group and green packaged tea solution obtained with a difference of -0.000535750 mpy corrosion rate be higher than the rate of corrosion control group because the average difference obtained is negative.

Thus, it can be concluded that the stainless steel wire immersion both in the group without treatment: control group, a group with a solution of jasmine, fruit-flavored, and green packaged tea has a great influence in increasing the corrosion rate obtained. It is seen from the results of statistical analysis that has been performed by One Way Anova test showed significance between these groups with $\mathrm{p}<0.05$.

\section{Discussion}

The results obtained indicate a difference in the corrosion rate of 0.0000493 mpy difference between the control group and the group jasmine packaged tea solution with the corrosion rate obtained was lower than the corrosion rate of the control group because the average difference obtained is positive. For the average difference between the control group and fruit-flavored packaged tea solution obtained with a difference of 0.000535000 mpy corrosion rate be lower than the rate of corrosion control group because the average difference obtained is positive. In addition, average difference between the control group and green packaged tea solution obtained with a difference of -0.000535750 mpy corrosion rate be higher than the rate of corrosion control group because the average difference obtained is negative.

Thus, it can be concluded that a good stainless steel wires immersion are in the group without treatment which is control group, a group with a solution of jasmine, fruit-flavored, and green packaged tea has a great influence in increasing the corrosion rate obtained. Of the four treatment groups, groups that provide the most influence on the corrosion rate of stainless steel wire is the group treated with green pacakged tea solution because of the difference in average by -0.000535750 which shows that the highest average rate of corrosion than with the other treatment groups and the p-value equal to $0.049<0.05$.

Corrosion known as metal damage that contacts with an aqueous environment and oxygen for their metallurgical factors (the material itself) and chemical reactions with the environment that cause deterioration in quality of metal materials. ${ }^{8,15,16}$

In the oral environment, orthodontic wire has a potency to release alloy. This can occur because of the influence of temperature changes, microflora, oral cavity enzymes and changes in the acidity $(\mathrm{pH})$ of saliva that may affect the stability of the metal ions. ${ }^{4,5,15}$ The acidity of saliva may change any time. 
Acidity changing of saliva can be happened because of the consumption of soft drinks, such as tea packaged drinks. ${ }^{9}$

Based on the results of $\mathrm{pH}$ measurement solution used in research, it is known that the $\mathrm{pH}$ of the solution with the addition of green packaged tea is 5.5. This indicates the acidic $\mathrm{pH}$ of the solution. Tea packaged drinks are acidic due to the oxidation process of the tea. The oxidation process occurs in thearubigin content contained in tea. If the content of thearubigin increase then the tea will be more acidic. Besides the acidic conditions in tea packaged drink also occurs because of the space between the surface of the beverage packaging. The room will be filled with oxygen during the packaging process. The oxidation reaction occurs between oxygen to the polyphenol compounds in tea. The longer the tea saved the oxidation process will also last longer so that the $\mathrm{pH}$ of tea packaged drink has decreased during the storage process.

\section{Conclusion}

These results indicate that green packaged tea can affect the rate of corrosion of stainless steel orthodontic wire. This is due to the average rate of corrosion of the orthodontic wire were soaking with a solution of green packaged tea has a higher value than the control group.

\section{Acknowledgment}

The author would like to thanks Faculty of Dentistry, Hasanuddin University, Makassar for helpful support in processing this journal.

\section{Conflict of Interest}

The authors reportno conflict of interest.

\section{References}

1. Ireland R. Kamus Kedokteran Gigi. Jakarta: EGC; 2012. p. 336.

2. Sambeta DC, Anindita PS, Juliatri. Effect of malocclusion of anterior teeth on psychosocial status in SMA Negeri 1 Luwuk students. J e-GiGi 2016;4: 59-63. (In Indonesia)
3. Rasyid NI, Pudyani PS, Heryumani JCP. Release of nickel and chromium ions in Australian wire and stainless steel in artificial saliva. Dent J 2014;47: 168-172. (In Indoensia)

4. Jura CO, Tendean LEN, Anindita PS. Amount of chromium (cr) and nickel (ni) ions of stainless steel orthodontic wire released in saliva immersion. e-GIGI 2015;3: 2-5. (In Indonesia)

5. Triaminingsih S. The difference in mechanical properties of stainless steel orthodontic wire due to the influence of the microstructure. JKGUI 2000;7(Special edition): 110115. (In Indonesia)

6. Ardhy S, Gunawarman, Affi J. The corrosion behavior of titanium in artificial saliva modified solutions for orthodontic applications. J Mek 2015;6: 585-593. (In Indonesia)

7. Sari DM, Handani S, Yetri Y. Control of the corrosion rate of st-37 steel in hydrochloric acid and sodium chloride medium using a tea leaf extract inhibitor (camelia sinensis). J Fis Univ Andalas 2013;2: 204-211. (In Indonesia)

8. Hasyim HS, Devi LS, Sumono A. The effect of immersion of nickel-titanium thermal orthodontic wire in packaged tea drinks on the deflection force of the wire. e-Jurnal Pustaka Kesehat 2016;4: 375-380. (In Indonesia)

9. Ludiana Y, Handani S. The effect of the concentration of tea leaf extract inhibitor (camellia sinensis) on the corrosion rate of schedule 40 grade b erw carbon steel. J Fis Unand 2012;1: 12-18. (In Indonesia)

10. Saranya R, Rajendran S, Krishnaveni A, et al. Corrosion resistance of metals and alloys in artificial saliva. Eur Chem Bull 2013;2: 163-170.

11. Heravi F, Moayed MH, Mokhber N. Effect of fluoride on nickel-titanium and stainless steel orthodontic archwires: an in-vitro study. J Dent Tehran Univ Med Sci 2015;12: 49-59.

12. Rajendran S, Paulraj J, Rengan P, et al. Corrosion behavior of metals in artificial saliva in presence of spirulina powder. J Dent Oral Hyg 2009;1: 1-2.

13. Butarbutar SL, Febrianto F. Edaq machine testing to measure the corrosion rate. Sigma Epsilon 2009;13: 54-58. (In Indonesia)

14. Situmeang MA, Anindita PS, Juliatri. The difference in the release of nickel and chromium ions in several brands of stainless steel wire soaked in vinegar. Pharmacon 2016;5: 252-258.

15. House K, Sernetz F, Dymock D, et al. Corrosion of orthodontic appliances-should we care? Am J Orthod Dentofac Orthop. 2008;133: 584-592.

16. Budianta T. Tea tannins, two considerations that need to be considered. Seri Kaji Ilm 1999;9. (In Indonesia)

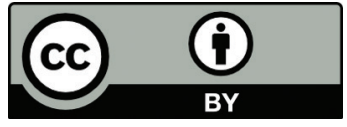

This work is licensed under a Creative Commons Attribution 